\title{
Internships enhancing entrepreneurial intent and self-efficacy: Investigating tertiary-level entrepreneurship education programmes
}

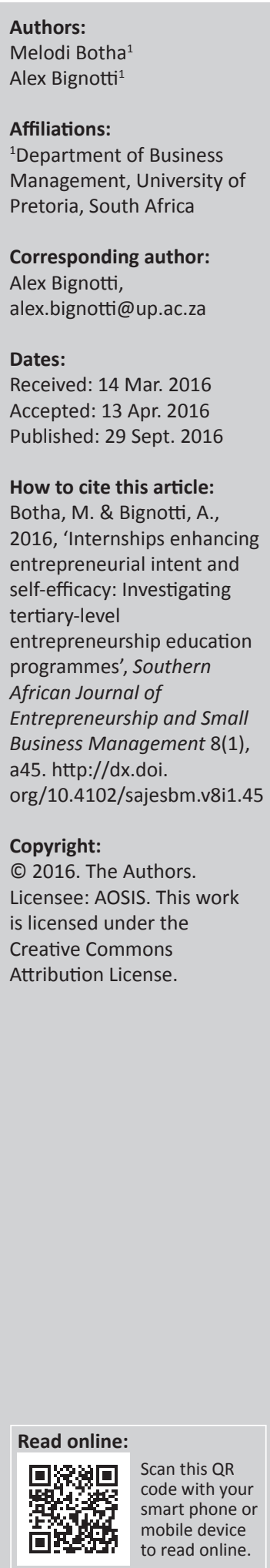

Background: Entrepreneurship education interventions are deemed effective when they enhance interns' entrepreneurial intent (EI) and entrepreneurial self-efficacy (ESE). Notwithstanding the emergence of internship as an experiential learning approach in entrepreneurship education, evidence about their potential to foster EI and ESE lacks systemisation.

Aim: The aim of this study was to determine whether internships enhance EI and ESE. Furthermore, to what extent South African tertiary institutions include internships in their entrepreneurship and management curricula and the obstacles to such inclusion.

Setting: South Africa has made a concerted effort to insert an entrepreneurship component across tertiary curricula. The evolution of this entrepreneurship component to experiential learning approaches is, however, unclear.

Methods: A qualitative research approach was followed. Firstly, it reviewed empirical evidence for the positive relationship between internships and EI and ESE. Secondly, it conducted a survey of entrepreneurship and business management programmes at all 23 South African tertiary institutions and content analysed the retrieved information to determine whether such programmes include internships. Finally, 10 experts were interviewed to unveil the constraints inhibiting the inclusion of internships in tertiary curricula.

Results: The results revealed empirical support for the positive influence of internships on both EI and ESE. Significant lack of inclusion of internships in tertiary curricula in South Africa emerged, owing mainly to administrative issues, curriculum re-design challenges, and lack of mentoring capacity.

Conclusion: Tertiary-level entrepreneurship education programmes should include an internship component. The paper suggested that tertiary institutions pilot-test the inclusion of internships with a small number of students and a selected cohort of small business owners.

\section{Introduction}

The impact of entrepreneurs, entrepreneurship and small business on economic growth and development is well researched and documented (Kibassa 2012:158; Mlatsheni \& Leibbrandt 2011:120; Thurik et al. 2008:673). For the economic potential of entrepreneurship to materialise, however, entrepreneurship has to be encouraged, by motivating individuals to become entrepreneurs and equipping them with the right skills to turn ideas into opportunities, and opportunities into successful ventures (Peltier \& Scovotti 2010:515; Volery et al. 2013:429). Fostering of entrepreneurship has therefore become an accepted wisdom in both economic management and government resolutions (Peltier \& Scovotti 2010:514; Vanevenhoven \& Liguori 2013:316).

Research has shown that universities play an important role in fostering entrepreneurship (Viviers, Solomon \& Venter 2013:2). Education is essential, not only to shape the mindsets of the youth but also to provide the skills and knowledge that are central to developing an entrepreneurial culture. A central premise of these statements is that entrepreneurship is not an innate characteristic but a phenomenon. Experience and the influence of teachers, parents, mentors and role models all play a role in shaping the development of entrepreneurs (Peltier \& Scovotti 2010:515; Volery et al. 2013:429).

Vanevenhoven and Liguori (2013:316) emphasise that individuals should be exposed to entrepreneurship education. These scholars found evidence across 70 countries that 
entrepreneurship graduates have significantly higher degrees of entrepreneurial motivation than non-entrepreneurship graduates (Vanevenhoven \& Liguori 2013:322).

The turbulent environment in which small businesses and entrepreneurs operate, however, requires universities to find hands-on, or experiential, learning approaches to prepare the entrepreneurs of the future (Nabi, Walmsley \& Holden 2013:1-2). Experiential learning is the process whereby knowledge is created through the acquisition and adaptation of experience: thus knowledge that results from the combination of acquiring and transforming experience (Radu Lefebvre \& Redien-Collot 2013:370). There has been increasing consideration of new approaches to curriculum pedagogy in universities, particularly in the form of workintegrated learning opportunities that aim to incorporate the workplace setting as a component of higher education (Alpert, Heaney \& Kuhn 2009:36; Anderson et al. 2012; Wan et al. 2013).

Alpert et al. (2009:37) highlight the fact that internships provide an experience of 'learning by doing' in a real business situation, but with guidance and support. Students with internship experience gain career advantages in the form of more job offers, less time spent looking for the right job after graduation and increased monetary compensation (Gault, Leach \& Duey 2010:85). Universities and colleges have been using internships as a means of providing business students with practical experience and preparing them for their future careers (Moghaddam 2011:287; Viviers et al. 2013:2). However, there seems to be a lack of South African tertiary institutions providing internships to their entrepreneurship students.

Despite the growing interest in internships by businesses, government and universities, limited scholarly research has been dedicated to the subject of internships in the entrepreneurship field (Alpert et al. 2009:37; Peltier \& Scovotti 2010:515). Conversely, a considerable number of studies have been conducted on what predicts entrepreneurial behaviour. In this research stream, there is widespread consensus that the construct of entrepreneurial intent (EI) is one of the best predictors of entrepreneurial behaviour (Ajzen 1991:181; Davidsson 1995:2; Krueger \& Carsrud 1993:196). A branch of this research stream has also investigated the antecedents, or triggering factors, of EI. Entrepreneurial self-efficacy (ESE), understood as the belief individuals have in their capabilities to perform entrepreneurial tasks and activities (Hmieleski \& Corbett 2008:486), has consistently been found to be an antecedent of EI (Kickul et al. 2008:329; Wilson, Kickul \& Marlino 2007:397). ESE may also mediate the relationship between other antecedent variables and EI (Zhao, Seibert \& Hills 2005:1270), and at the same time act as a moderator of these relationships (BarNir, Watson \& Hutchins 2011:287; Prabhu et al. 2012:573).

\section{The research problem}

There is consensus that entrepreneurially inclined individuals are more likely to start a business and that ESE further contributes to the formation of EI (Fayolle \& Liñán 2014:665; Kautonen, Van Gelderen \& Fink 2013:668; Sequeira, Mueller \& Mcgee 2007:288). Devising more effective entrepreneurship educational programmes requires a better understanding of the dynamics behind business start-up decisions (Liñán, Rodríguez-Cohard \& Rueda-Cantuche 2011:196). Given that the focus in entrepreneurship education is shifting towards experiential learning methods such as internships (Fayolle 2013:696), the question arises of whether or not internships enhance EI and ESE. To date, studies examining internships as antecedents of EI and ESE have been scarce in number and conducted in isolation. Taking the EI and ESE literature as point of departure, it is postulated that if internships do not increase the level of EI and ESE in individuals, then internship-based entrepreneurship education programmes have not been effective. In this paper, entrepreneurship education is broadly defined to include both education and training, which deal with knowledge transfer and skills transfer, respectively.

The aim of this paper is to conduct qualitative research by examining the empirical literature on whether or not internships enhance interns' levels of EI and ESE. In order to ground the present study in a South African context, it also conducts a survey approach whereby the information on university-level programmes in South Africa is content analysed. This is done to identify which tertiary institutions offer internships as part of their entrepreneurship and business management programmes. (In this paper, 'tertiary institutions' in South Africa are narrowly defined as South African universities and universities of technology or Technikons). The consideration of both entrepreneurship and business management programmes was dictated by the awareness that entrepreneurship education can also be offered as part of a business management programme (Martínez et al. 2010:23). Since very few entrepreneurship and business management education programmes at tertiarylevel in South Africa include an internship component, this paper contributes to entrepreneurship education practice by highlighting the role of internships in fostering EI and ESE, based on the empirical findings of previous studies. Reasons for the exclusion of internships are highlighted and possible solutions are presented.

This paper sets off by providing a brief overview of the supporting literature and then formulates research propositions. Thereafter, the research methodology is described and the empirical findings presented. The findings and their implications are discussed. Lastly, the limitations of the study are presented and recommendations for future research are highlighted.

\section{Literature review}

\section{Experiential learning in entrepreneurship education}

Notwithstanding the novelty that entrepreneurship represents in the sphere of higher education, it is one of the fastest growing tertiary-education fields, with the number of entrepreneurship degrees and courses multiplying every 
year (Peltier \& Scovotti 2010:515). Recently, providing entrepreneurship education and enhancing interest in and understanding of small businesses have been of increasing interest in higher education (Varghese et al. 2012:358). Previous studies have examined factors influencing EI, which include intrinsic personality traits, perceived barriers and support, and the socio-political-economic context of entrepreneurship (Fayolle, Gailly \& Lassas-Clerc 2006:702).

In the entrepreneurship education field, the belief that traditional classroom-based teaching methods are inadequate to equip students with the necessary tools and skills to start and run their own business ventures is gaining increasing consensus (Varghese et al. 2012:361). As a consequence, traditional teaching methods must be complemented by innovative ways of thinking, diverse skills and new modes of behaviour to develop fully entrepreneurial approaches to education (Alpert et al. 2009:36; Peltier \& Scovotti 2010:515; Zhao 2013:444). Conversely, some studies have observed that experiential internship programmes can have an effect on students' understanding, attitudes, perceptions, and intentions with regard to entrepreneurship and small businesses (Varghese et al. 2012:358; Volery et al. 2013:431).

From the above discussion, it is evident that traditional teaching methods are not adequate in fostering students' entrepreneurial behaviour. Entrepreneurship education specifically necessitates collaboration between traditional and new innovative approaches to education, one of which is the experiential element offered by internships.

\section{Internships as a form of experiential learning}

Much has been written about the value of experiential learning (Martínez et al. 2010:11; Mason \& Arshed 2013:457). Experiential learning theory posits that effective learning occurs when students are actively involved with an experience and then reflect on that experience. The activities involved in experiential learning help students integrate theory and real-world practice (Peltier \& Scovotti 2010:515; Pittaway et al. 2011:48).

An internship, as mentioned before, is a form of experiential learning. An internship may be defined broadly as a temporary work position with an emphasis on education rather than employment (Weible 2009:59). There are varying definitions of internships (Moghaddam 2011:287; Zhao 2013:445), but they all concur on some core characteristics. For the purposes of this study, an internship is defined as structured and career-relevant work in an external organisation, occurring in a controlled experiential environment, where a student receives academic credit and/or applicable knowledge.

'Learning by doing', 'action learning' and 'gaining experience' are seen to be some of the main benefits that students gain and are often judged by students to be superior forms of learning when compared with traditional forms experienced in the curriculum (Chen \& Shen 2012:35; Pittaway et al. 2011:53).
According to Alpert et al. (2009:37), the many benefits of internships have been well documented in several studies. For students, an internship provides an experience of 'learning by doing' in a real business situation, but with guidance and support. Internships bridge the gap between theory and practice and between classroom education and real-industry life. They provide a more valuable learning experience, enhance the meaning of the academic programme and create feelings of personal and social efficacy (Alpert et al. 2009:37; Daugherty 2011:470).

According to Kim and Park (2013:72), an internship can provide participants with the opportunity of learning what the industry offers, which may be different from what they learn in the classroom and can certainly influence a student's career choice in either a positive or negative manner (Chen \& Shen 2012:30; Daugherty 2011:470). More specifically, internships in an entrepreneurial venture or small business may foster the intern's decision to pursue an entrepreneurial career. The experience in this type of internship is likely to have a significant impact on whether students decide to join the organisation and if they eventually aim for a career in that direction (Nabi et al. 2013:3; Zhao 2013:445).

\section{Entrepreneurial intent and entrepreneurial self-efficacy}

The attempt to explain the decision to start a business venture has given rise to a body of research that has investigated the factors triggering this decision. One of the most widely reported factors is the construct of EI.

EI may be defined as a conscious awareness and conviction by individuals that they intend to set up a new business venture and plan to do so in the future (Buelens \& Izquierdo 2008:219; James \& Bell 2013:96). A great part of the research on EI has been derived from early works in the psychological field that focused on understanding human behaviour, such as Ajzen's (1991) Theory of Planned Behaviour, which advances intention as a robust predictor of behaviour. Early works in the field of entrepreneurship were also grounded in the construct of EI, such as Shapero and Sokol's (1982) Entrepreneurial Event Model, Bird's (1988) EI Model and Boyd and Vozikis' (1994) Model of Entrepreneurial Intentionality, to name a few.

Intention-based models have attracted much attention from researchers, as they offer an opportunity to increase our understanding of and predictive ability for entrepreneurship (James \& Bell 2013:96). Studies in the area of student propensity (intentionality) have ranged considerably between narrow personality-trait perspectives to broader perspectives taking into consideration social and environmental influences (De Clercq, Honig \& Martin 2012:653-654).

According to Buelens and Izquierdo (2008:219), developing of attitudes and intentions towards entrepreneurship is paramount in business start-up behaviour. Business start-up has been viewed as intentional and as best predicted by EI (Gird \& Bagraim 2008:719). Business start-up activities are 
not necessarily restricted to one or the other motivational categories but, in their intentionality dimension, constitute a combination of both the push and pull factors. The journey to entrepreneurship is not a function of a single motivating factor but a combination of them (Nabi et al. 2013:9). However, there is evidence that entrepreneurial behaviour is preceded by EI, which is influenced by an individual's entrepreneurship education (Sánchez 2013:448).

Within the field of research on university students' business start-up decisions, there is an over-abundance of studies that indicate a relatively high level of EI in the student population. There is still little consensus, however, on how this intention is formed, and research has revealed that different contextual factors may be related to university students' motivation to start their own businesses, such as formal aspects (higher education courses) or informal ones (family and significant others). The aforementioned formal and informal elements are pivotal regarding business start-up, pulling graduates by affording education and support, as well as pushing graduates by forcing them to consider venture creation in the absence of traditional organisational jobs or high graduate unemployment (Nabi et al. 2013:8).

James and Bell (2013:99), for instance, found that between $30 \%$ and $40 \%$ of participants in an entrepreneurship education programme had no desire to start a business immediately after completing the programme, whereas $70 \%$ of them wished to start a business within 5 to 10 years after the programme. Similarly, Viviers et al. (2013:10) indicate that there is a shift in favour of entrepreneurship as a career choice 5 years after graduation. These findings indicate that individuals undertaking entrepreneurship education develop EI, but they wish to start a business only in the medium term. It can be postulated that between completing the entrepreneurship education course and starting a business they want to gain some experience, knowledge and confidence. As discussed earlier, internships may successfully provide students with this learning experience before they embark on their own business.

In sum, students' EI is linked to their behavioural attitudes (one of which is wanting to gain experience before starting up), and the internship experience could enhance individuals' self-confidence and maturity (Kim \& Park 2013:77), fostering students' EI. By doing this, students becomemore independent, ambitious and focused on becoming entrepreneurs (Daugherty 2011:470; Volery et al. 2013:431). These considerations lead to the first proposition.

Proposition 1: Internships as a form of experiential learning enhance students' EI.

A considerable number of studies within the EI literature have investigated the antecedents of EI, or the factors that foster the development of the intention to start a business. The approaches followed by different authors are varied. Some authors have focused on the impact on EI of personal characteristics and contextual factors, such as personal traits
(De Pillis \& DeWitt 2008), learning orientation and passion for work (De Clercq et al. 2012), family business background (Drennan, Kennedy \& Redfrow 2005; Zellweger, Sieger \& Halter 2011), role models (Van Auken, Fry \& Stephens 2006), peer influence (Falck, Heblich \& Luedemann 2012) and different types of entrepreneurial or other experiences (Drennan et al. 2005; Quan 2012). Other authors (Liñán et al. 2011) have based their work on the Theory of Planned Behaviour, also in an educational context (Do Paço et al. 2011), and have confirmed the validity of this theory in examining how EI is developed.

One of the most commonly cited antecedents of EI is ESE. Self-efficacy is a construct first devised by Bandura (1977) in the psychological field, and is understood as the strength of people's convictions of their own effectiveness in executing the behaviour required to achieve certain outcomes (Bandura 1977:79). People with a high level of self-efficacy tend to set challenging goals, persist even in the face of failure and approach difficult tasks as challenges to be mastered rather than issues to be avoided (Kibassa 2012:161). In an entrepreneurship context, ESE is defined as the belief individuals have in their capability to perform entrepreneurial tasks and activities (Hmieleski \& Corbett 2008:486). Many authors have devoted their research efforts to the investigation of the relationship between EI and ESE (see for example: BarNir et al. 2011; Boyd \& Vozikis 1994; Kickul et al. 2008; Prabhu et al. 2012; Wilson et al. 2007; Zhao et al. 2005), and have found ESE to relate to the development of EI, as well as to function as both mediator and moderator of the effect of other variables on EI. Individuals with higher ESE are thus expected to have higher EI.

As to the understanding of how ESE is developed, it is worth mentioning that Bandura (1977:80-83) advocates that self-efficacy can be developed through performance accomplishments and vicarious experience, among other factors. The former refers to a person experiencing success in performing certain behaviour, whereas the latter is concerned with a person's observation of other people succeeding at a difficult task. Both factors strengthen self-efficacy by helping individuals to have a stronger belief in their ability to perform certain tasks successfully.

It can be postulated that both performance accomplishments and vicarious experience are enabled by internships, thus allowing for the development of interns' ESE. In fact, internship opportunities, especially in the small or start-up business sector, can benefit students by providing a rich learning experience that models future work environments and allows them to develop valuable skills that will prove beneficial in a variety of professional endeavours (Narayanan, Olk \& Fukami 2010:62; Varghese et al. 2012:357). Moreover, entrepreneurship internships provide a good opportunity to follow an entrepreneur and learn essential skills in starting and running a new business (Nabi et al. 2013:3; Zhao 2013:445). Research has shown that the opportunity to acquire skills and 
experience achievement through applied internships reinforces ESE, which in turn influences EI (Narayanan et al. 2010:62; Varghese et al. 2012:358).

Based on the above discussion, this paper investigates whether internships enhance interns' levels of ESE. This leads to the formulation of the second proposition.

Proposition 2: Internships as a form of experiential learning enhance students' ESE.

The variables included in the present investigation, and the propositions linking internships to EI and ESE, are graphically represented in Figure 1.

The South African government currently spends large sums earmarked for the development of youth entrepreneurship (Herrington \& Kew 2014:47). However, the government initiatives put in place since 1994 have not achieved the desired results, partly because of a widespread lack of awareness among the target population of these initiatives (Herrington, Kew \& Kew 2015:40). Contextualising the present study in South Africa, and based on the above literature review, it can be postulated that internships should be included in entrepreneurship and business management programmes at South African tertiary institutions, as an experiential learning component of entrepreneurship education at tertiary-level education.

Proposition 3: Internships as a form of experiential learning are included in entrepreneurship and business management programmes of South African tertiary institutions.

The following section describes the research methodology adopted by the present study, whereby information from the South African tertiary institutions was investigated to verify proposition 3.

\section{Methodology}

This paper follows a pragmatist philosophical paradigm, as it is concerned with the practicality of internships with a view to enhancing EI and self-efficacy (Saunders \& Tosey 2012:58). Although the pragmatic approach is more used in mixedmethod research, the researchers have adopted 'the scientific notion that social inquiry was able to access the "truth" about the real-world solely by virtue of a single scientific method'

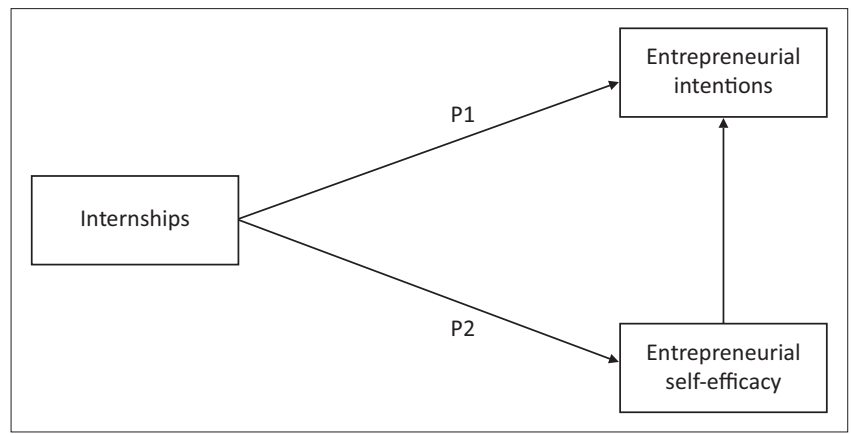

FIGURE 1: Conceptual framework of the relationships between internships, EI and ESE.
(Mertens 2005:26). The relevance of including internships as a component of entrepreneurship and business management curricula at tertiary institutions is only justified by the verification from experience in research of the value of internships in fostering EI and ESE.

In order to verify the above propositions, this paper followed a qualitative research approach, laid out in three consecutive steps. Firstly, it reviewed empirical research to find support for the positive relationship between internships and the constructs EI and ESE, using the major online databases for the discipline of entrepreneurship. Secondly, it carried out a survey of entrepreneurship and business management programmes at South African tertiary institutions, using publicly available information and telephone communication. The retrieved information was then content analysed to determine whether such programmes include internships in their curricula. Finally, 10 experts in the field of entrepreneurship education at tertiary institutions were interviewed in order to understand, (1) the extent to which they were aware of the positive relationship between internships and the development of EI and ESE; (2) why internships were included in tertiary-level entrepreneurship education programmes, or if not, why not and (3) what constraints they perceived to exist that might prevent their including internships in tertiary-level entrepreneurship education programmes.

The review of empirical literature pertaining to the relationships between internships and EI and ESE was conducted through the major online databases for the discipline of entrepreneurship: EBSCOhost, ProQuest, Emerald and Google Scholar. The search was set to find sources dating from 2008 to 2014. The choice of conducting the literature review over the past six-and-a-half years of research was dictated by the decision to situate the present study within the most recent discussions about internships as a form of experiential learning in entrepreneurship education. The keyword combinations used in the search were the following: 'internship' and 'entrepreneurial intent'; 'internship' and 'entrepreneurial self-efficacy'; 'work experience' and 'entrepreneurial intentions'; and 'work experience' and 'entrepreneurial self-efficacy'. In order to limit the search to works pertaining to internships, EI and ESE specifically, while not restricting the search excessively, the search used the above-mentioned keywords in the 'abstract' field. Thereafter, 25 sources were deemed to pertain to the subject matter of investigation and were retrieved for further analysis. Of these, 18 were journal articles, one was a doctoral thesis, two were conference papers and four were working papers. These data were content analysed to identify whether or not they empirically supported the propositions of this paper.

The survey approach entailed a content analysis whereby the entrepreneurship and business management programmes offered at all 23 South African tertiary institutions were investigated. This investigation was performed in order to 
identify which tertiary institutions include internships as a component of their entrepreneurship and business management curricula. The data was content analysed to substantiate the relevance of internships for entrepreneurship education practice in South Africa. University-level entrepreneurship and business management programmes up to Master's level were analysed by referring to online webbased programme brochures. When these were insufficient, telephone interviews were conducted. MBA programmes were excluded from the investigation, since they provide education to individuals already in management positions, thus rendering the inclusion of internships redundant.

For the interview part of this study, all 23 South African tertiary institutions were contacted. The researchers requested an interview with the person in charge of entrepreneurship and business management curriculum development, or another expert involved in curriculum design, in order to obtain possible reasons for internships not being included in their curricula at their institutions.

The trustworthiness of the present qualitative research was guaranteed by (1) the use of precise search criteria in the review of empirical literature; and (2) the adoption of a survey approach whereby the data on university degrees was content analysed; namely, the assessment of whether entrepreneurship and business management degrees include internships in their curricula. These procedures minimised the level of researcher bias present in this paper, thus implementing one of the validation strategies used in qualitative research (Creswell 2013:251).

\section{Findings \\ Review of empirical literature}

The review of empirical studies that provide support for the relationship between internships and interns' levels of EI and ESE is summarised in Table 1. Eleven sources of the 25 originally identified were discarded, as further analysis revealed that they did not pertain to the present investigation or had not conducted empirical analyses. This led to 14 studies being included in this investigation, all empirically supporting Proposition 1 and Proposition 2.

As shown in Table 1, out of the 14 studies in support of either or both Proposition 1 and Proposition 2, 13 studies report a positive influence of internships on the development of EI and six studies support the influence of internships on ESE.

\section{Survey and content analysis of entrepreneurship and business management programmes}

The survey of the content of entrepreneurship and business management programmes, which used publicly available information and telephone communication, successfully retrieved the content of such programmes for all 23 South African tertiary institutions. A comprehensive reading list of the sources of this survey is available in Appendix 2.
The survey performed a content analysis of the data relating to the internship component of South African tertiary institutions' entrepreneurship and business management programmes. The results of this content analysis are outlined in Appendix 1. The results reveal that Durban University of Technology is the only tertiary institution that has a programme including internships as part of its curriculum.

\section{Interviews with experts in the field of entrepreneurship education}

The next step involved interviews (personal, telephonic or via email) with the relevant academics in the field of entrepreneurship at the various tertiary institutions in South Africa. Ten experts in the field of entrepreneurship education at tertiary-level were interviewed; they were affiliated with the following tertiary institutions: Central University of Technology, Stellenbosch University, University of Johannesburg, University of Pretoria, University of the Free State, Vaal University of Technology, and Walter Sisulu University. The experts were identified according to the following process:

- Step 1: All 23 South African universities and universities of technology were considered.

- Step 2: A telephonic and Internet-based search of the lecturers specialising in entrepreneurship at these tertiary institutions was performed, and 109 entrepreneurship educators were listed.

- Step 3: At least three entrepreneurship educators from each tertiary institution were contacted and asked to participate in an interview on the potential of internships in tertiary-level entrepreneurship and business management programmes to foster EI and self-efficacy.

- Step 4: Ten experts agreed to be interviewed.

The interviews covered the following aspects, as previously mentioned: (1) the extent to which they are aware of the positive relationship between internships and the development of EI and ESE; (2) why internships were included in university-level entrepreneurship education programmes, and if not, why not and (3) what constraints they perceived to exist that might prevent their including internships in university-level entrepreneurship education programmes. Academics at the Durban University of Technology were not, however, available for interviews to provide reasons why they are including internships and the advantages of internships for their students.

Eight experts acknowledged that they were aware of the positive role played by internships in fostering interns' EI and ESE.

As for the reasons why internships are not included in entrepreneurship and business management programmes, interviewee D and interviewee F referred to the lack of a sufficiently vast network of businesses in their geographical area to enable the inclusion of internships in their programmes. (Some institutions, despite facing the same 
TABLE 1: Literature-based empirical support for propositions.

\begin{tabular}{|c|c|c|c|}
\hline Author(s) & $\begin{array}{l}\text { Purpose of } \\
\text { study }\end{array}$ & $\begin{array}{l}\text { Proposition } \\
\text { supported }\end{array}$ & $\begin{array}{l}\text { Findings in } \\
\text { support }\end{array}$ \\
\hline $\begin{array}{l}\text { Backes-Gellner \& } \\
\text { Moog } 2008\end{array}$ & $\begin{array}{l}\text { To study people's El depending on their composition of } \\
\text { human and social capital, based on an extension of the } \\
\text { Jack-Of-All-Trades Theory (Lazear 2005). }\end{array}$ & P1 & $\begin{array}{l}\text { Internships have a positive impact on El for individuals who have a } \\
\text { balanced set of human and social capital. }\end{array}$ \\
\hline Basu \& Virick 2008 & $\begin{array}{l}\text { To explore entrepreneurial intentions and their antecedents } \\
\text { among university students, based on the Theory of Planned } \\
\text { Behaviour (Ajzen 1991). }\end{array}$ & $\mathrm{P} 1, \mathrm{P} 2$ & $\begin{array}{l}\text { Prior experience of starting a business is significantly related to } \\
\text { positive attitudes toward an entrepreneurial career [i.e. EI] and } \\
\text { greater ESE. This implies that internships in new ventures may } \\
\text { contribute to higher degrees of ESE and EI. }\end{array}$ \\
\hline Kickul et al. 2008 & $\begin{array}{l}\text { To examine the role of leadership experience, work } \\
\text { experience, parental role models and ESE in fostering El, } \\
\text { with the focus on gender differences. }\end{array}$ & P1, P2 & $\begin{array}{l}\text { Previous work experience, which may be gained through internships, } \\
\text { has a positive direct impact on ESE. It also has a positive influence on } \\
\text { EI, mediated by its effect on ESE. }\end{array}$ \\
\hline Cruz et al. 2009 & $\begin{array}{l}\text { To assess the effectiveness of educational programmes on } \\
\text { innovation and business success aimed at entrepreneurs. }\end{array}$ & P1 & $\begin{array}{l}\text { Entrepreneurs with more accumulated work experience show } \\
\text { themselves to be more innovative (innovation constituting the } \\
\text { essence of entrepreneurship). It is recommended that individuals } \\
\text { work in internship positions while studying for a degree. }\end{array}$ \\
\hline Lucas et al. 2009 & $\begin{array}{l}\text { To explore the relative influence of a range of experiences } \\
\text { in the workplace on university students' entrepreneurial } \\
\text { and technology self-efficacy. }\end{array}$ & P2 & $\begin{array}{l}\text { Work experience through internships raises students' entrepreneurial } \\
\text { and technology self-efficacy, when the internship is in line with } \\
\text { students' field of study. Performance feedback is given and students } \\
\text { have a high consideration of their performance at work. }\end{array}$ \\
\hline Dohse \& Walter 2010 & $\begin{array}{l}\text { To assess the extent to which entrepreneurship education } \\
\text { at tertiary-level influences students' El in three study fields: } \\
\text { computer science, electrical engineering, and business. }\end{array}$ & P1 & $\begin{array}{l}\text { Entrepreneurship education contributes to motivating students to } \\
\text { become entrepreneurs, while internships at start-up firms contribute } \\
\text { to students' perceived entrepreneurial competences. Both positively } \\
\text { influence students' El. }\end{array}$ \\
\hline Dutta, Li \& Merenda 2010 & $\begin{array}{l}\text { To explore how prospective entrepreneurs benefit from } \\
\text { both specialised entrepreneurship education and a } \\
\text { diversified educational experience. }\end{array}$ & P1 & $\begin{array}{l}\text { Specialised entrepreneurship education, encompassing internships in } \\
\text { one or more entrepreneurial ventures, has a positive impact on the } \\
\text { likelihood of future venture creation and, thus, on El. }\end{array}$ \\
\hline $\begin{array}{l}\text { Keat, Selvarajah \& } \\
\text { Meyer } 2011\end{array}$ & $\begin{array}{l}\text { To examine the relationship between university students' } \\
\text { El and entrepreneurship education, entrepreneurial } \\
\text { internship programmes, role models, family business } \\
\text { background and demographic variables. }\end{array}$ & P1 & $\begin{array}{l}\text { Students with working experience gained through internships display } \\
\text { higher El. }\end{array}$ \\
\hline Maina 2011 & $\begin{array}{l}\text { To explore the role that colleges can play in enhancing El } \\
\text { among the youth. }\end{array}$ & $\mathrm{P} 1, \mathrm{P} 2$ & $\begin{array}{l}\text { College students' previous entrepreneurial experience, through } \\
\text { either family business or employment in small-scale businesses } \\
\text { (which can be seen as a proxy for internships), positively } \\
\text { influences their ESE, which in turn impacts on their El. }\end{array}$ \\
\hline Wang \& Verzat 2011 & $\begin{array}{l}\text { To compare the development of El between students of } \\
\text { two prestigious engineering schools. }\end{array}$ & P1 & $\begin{array}{l}\text { Students studying at the tertiary institution whose curriculum } \\
\text { included longer internships and international internships had higher } \\
\text { levels of El. }\end{array}$ \\
\hline Varghese et al. 2012 & $\begin{array}{l}\text { To study the process of student learning in a small business } \\
\text { internship programme. }\end{array}$ & $\mathrm{P} 1, \mathrm{P} 2$ & $\begin{array}{l}\text { The internship programme contributed to students' higher ESE } \\
\text { and El. It was also beneficial to students in terms of knowledge } \\
\text { acquisition, ability to situate their learning in the business, acquisition } \\
\text { of important professional skills and the ability to see how they } \\
\text { contributed directly to the company. }\end{array}$ \\
\hline Bignotti 2013 & $\begin{array}{l}\text { To investigate the factors relating to high school students' } \\
\text { entrepreneurial-career-choice intention (EI). }\end{array}$ & P1 & $\begin{array}{l}\text { The study found that } \mathrm{El} \text { is related to a number of factors, including } \\
\text { work experience in the family business or in the form of part-time or } \\
\text { holiday jobs. It is recommended that students be offered the } \\
\text { opportunity to be exposed to work experience, such as that acquired } \\
\text { during internships. }\end{array}$ \\
\hline
\end{tabular}

El, entrepreneurial intent; ESE, entrepreneurial self-efficacy.

challenge, have redesigned their programmes to include compulsory 'work-integrated learning', as stated by interviewee C.) Interviewee $\mathrm{D}$ also mentioned the administrative challenge of finding internships for a large number of students, while interviewee J admitted the lack of enough knowledge to warrant the inclusion of internships and the management thereof. Additionally, interviewee $\mathrm{G}$ and interviewee I mentioned small business owners' lack of time and financial resources as major obstacles. Lack of administrative and other resources is also a constraint, as stated by interviewee $\mathrm{H}$. It appears from the interviews that some universities - such as Stellenbosch University and the University of the Free State - support internships, but on an ad-hoc basis. They encourage students to find internships and they support them in securing these positions. The initiative, however, is taken by the students, usually at postgraduate level. Finally, interviewees A, B and G highlighted other experiential learning components in their programmes, which are meant to produce the same results - in terms of skills and knowledge development - as internships. These other forms of experiential learning range from having lecturers who have a vast experience in entrepreneurship and business, to creative problem-solving and effectuation learning techniques. From the perspective of students, interviewees $\mathrm{E}$ and $\mathrm{G}$ attested to an unsatisfactory experience on the part of students who managed to secure an internship.

With regard to possible constraints hindering universities from including internships in tertiary-education programmes, most experts mentioned the university's lack of resources to manage and control internships, issues of curriculum redesign and academic credits, labour legislation constraints, and the lack of willingness and capacity of small business owners to mentor interns. Interviewees $\mathrm{H}$, I and $\mathrm{J}$ also mentioned that whereas internships in large companies are more readily available, internships in small businesses are 
not easily found and are essentially different. According to them, the challenge lies in identifying the right internships, which ultimately means knowing which entrepreneur profile is most suited to accommodate an intern successfully.

\section{Discussion of findings}

The review of empirical literature conducted in this paper reveals that there is support for the proposition that internships as a form of experiential learning enhance students' EI (P1). It appears, therefore, that when entrepreneurship education programmes include internships in their curriculum, participants are more likely to develop the intention to start a business. Some of the studies analysed in this paper reported empirically about the positive relationship between internships and EI, even outside an entrepreneurship education context. In other words, people who have an internship experience appear to have higher EI, even though they are not part of a formal entrepreneurship education intervention. This is in line with previous research about the impact of previous work experience on start-up intentions and activities (Gabrielsson \& Politis 2012; Kemelgor, D’Souza \& Henley 2011).

The review of empirical literature also provides evidence for the support of the proposition that internships as a form of experiential learning enhance students' ESE (P2). This means that the hands-on experience gained during internships helps students to have a higher level of confidence in their capabilities to start and run their own business. This finding confirms the argument that internships are an effective learning method whereby participants acquire a greater knowledge of and confidence in the professional field underlying the internship experience (Kuijpers, Meijers \& Gundy 2011:26).

Moreover, as can be noted in Table 1, most of the studies that empirically support the positive role of internships for the formation of ESE also give empirical evidence for the positive influence that internships have on EI. This finding can be attributed to the fact that ESE does not lead to entrepreneurial behaviour - such as business start-up activities - directly, but it influences entrepreneurial behaviour through its impact on EI (Kickul et al. 2008; Wilson et al. 2007; Zhao et al. 2005).

The implication for theory of these findings is that internships should be included in EI- and ESE-based models of entrepreneurial behaviour as one of the factors influencing these two constructs. As this paper's review of empirical literature reveals, few studies have analysed the influence of internship on the development of EI and ESE (Alpert et al. 2009:37; Peltier \& Scovotti 2010:515).

The relevance of internships for enhancing EI and ESE in a South African context was corroborated by the universitylevel entrepreneurship- and business management education survey whereby the data was content analysed in this paper. The results reveal that only one tertiary institution, the Durban University of Technology, includes internships as part of its curriculum. Proposition 3 is thus only supported in the case of the Durban University of Technology, one out of 23 South African tertiary institutions. There is a significant lack of inclusion of internships as a form of experiential learning in South African tertiary-level entrepreneurship and business management education programmes. For practice, these findings imply that entrepreneurship- and business management education programme administrators at South African tertiary institutions should devise an experiential learning module based on an internship experience. From a student's perspective, the findings of this study suggest that a more effective acquisition of EI and ESE can be gained in university programmes that include an internship as part of the curriculum.

The interviews conducted with experts in the field of entrepreneurship education at tertiary-level revealed that there is widespread awareness of the positive role played by internship in enhancing interns' EI and ESE. In light of this, the prevalent lack of inclusion of internships in university entrepreneurship and business management programmes seems contradictory. However, a number of reasons for this lack emerged from the interviews, pertaining mainly to administrative and conceptual difficulties. Administrative issues include: tertiary institutions' lack of sufficient internal resources - human and financial - to scout, manage and control internships; difficulty in finding internships for all enrolled students due to lack of enough small businesses; and challenges related to curriculum redesign. Conceptual reasons for not including internships pertain mainly to some experts' belief that there are other experiential learning curriculum components that are at least as effective as internships and easier to administer.

The constraints that were mentioned by the experts attest to the difficulty - mainly administrative - in successfully integrating internships into university programmes. Another considerable constraint is small business owners' lack of capacity to mentor interns successfully. One possible solution to administrative challenges would be to pilot-test the inclusion of internships in a university programme with a manageable number of students. In this way, finding a number of suitable internships corresponding to the number of students would be more achievable. Moreover, such an initiative would not require significant investment in terms of academic staff and time. Finally, this solution would allow for establishing a stable relationship with a few, carefully selected, small business owners. This pilot-test inclusion of internships could be scaled up once it was established and had produced the intended results.

\section{Conclusion}

The understanding of how EI can be fostered lies at the heart of research in the entrepreneurship field. Following the first steps in the psychological study of human behaviour by Ajzen (1985) and Bandura (1977), many entrepreneurship scholars have studied entrepreneurial behaviour and, more specifically, business start-up decisions from the perspective 
of intention. Within this branch of entrepreneurship research, EI is widely viewed as a robust predictor of the decision to start a business venture, with ESE being one of the most cited antecedents of EI.

Entrepreneurship education offers another angle from which the promotion of business venture start-up can be examined. The number of entrepreneurship education programmes has multiplied in recent years (Peltier \& Scovotti 2010:515) based on the realisation that entrepreneurship can be taught (Kuratko 2005:580). The focus in this field, as in other educational fields, has shifted to experiential learning methods, including internships, which, because of the first-hand experience and exposure to entrepreneurship they provide, are believed to be effective in enabling and encouraging people to start their own businesses (Zhao 2013:445).

Bringing together the intention-based and entrepreneurship education perspectives, this paper addressed one specific aspect of the formation of business start-up decisions, namely, whether or not internships enhance interns' EI and ESE levels. It conducted a review of empirical literature and investigated the results of empirical studies on the relationship between internships, on the one hand, and EI and ESE on the other. Thereafter, it followed a survey approach which content analysed the information on which South African universities offer entrepreneurship and business management programmes up to Master's level, and whether they include internships in their curricula. Finally, it conducted interviews with experts in the field to assess the level of awareness about the potential of internships to raise interns' EI and ESE, understand the reasons why internships are or are not included in university programmes, and to explore the possible constraints faced when considering including internships in university curricula.

The findings of this qualitative research are that there is empirical support for the positive influence of internships on the development of interns' EI and ESE. It was also found that there is a significant lack of inclusion of internships in South African tertiary institutions' entrepreneurship and business management programmes. The reasons for this lack of inclusion of internships pertain mainly to tertiary institutions' administrative capacity issues; difficulties in scouting, managing and controlling internship programmes for students; issues with curriculum redesign; and small business owners' lack of capacity to mentor interns. In the light of the results of this paper, it is recommended that university-level entrepreneurship education programmes in South Africa include internships as part of their curricula. It is suggested that tertiary institutions pilot-test the inclusion of internships with a small number of students and a selected cohort of carefully selected small business owners.

\section{Limitations and future research}

As for all qualitative research studies, the findings of this paper should be interpreted taking into account certain limitations. Firstly, the literature review methodology employed could have excluded some empirical studies, owing to the search criteria that were utilised. Some studies may also have been overlooked on account of some degree of subjectivity on the part of the researchers in retrieving studies that were deemed relevant to the present analysis.

The relatively small number of empirical studies on the topic of internships and their impact on interns' EI and ESE that were found in this study gives an indication of the research gap that exists in this field. There is a need to conduct more empirical investigations into the positive role that internships play in fostering EI and ESE. This recommendation stems from the results of the literature review (Table 1) conducted in this paper, which encompassed the global domain of entrepreneurship and thus affects the entire body of research on the topic of this paper. A meta-analysis could be conducted on all the studies on this topic to test the relationship between internships, EI and self-efficacy even further.

More specifically, research on this topic needs to move forward to the investigation of what internship components make internships more effective in promoting the formation of EI and ESE. This would encourage research that could contribute to the understanding of how to devise internship experiences that effectively increase interns' levels of EI and ESE. More evidence on the positive influence of internship experiences on the formation of EI and ESE would corroborate the earlier conclusion that internships should be part of entrepreneurship education programmes.

Bearing in mind that EI and ESE do not always translate into entrepreneurial behaviour in the form of starting a business venture (Ajzen 1985:11; Boyd \& Vozikis 1994:70), future research should investigate the possible mechanisms according to which internships may contribute to people's start-up activities. For this type of analysis to take place, it is necessary that longitudinal studies be conducted, measuring both the development of EI and ESE in the short term and business start-up activities in the long term.

In order to situate the analysis of the role of internships in enhancing levels of EI and ESE in the context of entrepreneurship education at university-level, future research could compare the levels of EI and ESE of students enrolled in internship-inclusive entrepreneurship programmes with those of students enrolled in traditional entrepreneurship programmes.

Finally, with the objective of identifying and sharing best practices in the inclusion of internships in university programmes, future research could conduct case study investigations of the tertiary institutions - in South Africa and outside of South Africa - that have successfully integrated internships in their curricula.

\section{Acknowledgements}

The authors acknowledge Nokumuka Dube for providing part of the background study to this paper. 


\section{Competing interests}

The authors declare that they have no financial or personal relationships which may have inappropriately influenced them in writing this article.

\section{Authors' contributions}

The authors collaborated during the literature-study, analysis and article-writing phases of this paper. M.B. was the project leader, formulating the concept and devising the structure of the paper. A.B. was responsible for the review of empirical literature and survey approach. Both authors conducted interviews with experts in the field of entrepreneurship education.

\section{References}

Aizen, I., 1985, 'From intentions to actions: A theory of planned behavior', in J. Kuhl \& J. Beckmann (eds.), Action control: From cognition to behavior, Springer, Heidelberg, Germany.

Ajzen, I., 1991, 'The theory of planned behavior', Organizational Behavior and Human Decision Processes 50(2), 179-211. http://dx.doi.org/10.1016/0749-5978(91) 90020-T

Alpert, F., Heaney, J. \& Kuhn, K.L., 2009, 'Internships in marketing: Goals, structures and assessment - Student, company and academic perspectives', Australasian Marketing Journal 17(1), 36-45. http://dx.doi.org/10.1016/j.ausmj.2009. 01.003

Anderson, E., Johnston, N., Iles, L., Mcrae, N., Reed, N. \& Walchli, J., 2012, 'Cooperative education and student recruitment, engagement and success: Early findings from a multi-institutional study in British Columbia', Journal of Cooperative Education and Internships 46, 58-76.

Backes-Gellner, U. \& Moog, P., 2008, Who chooses to become an entrepreneur? The Jacks-of-All-Trades in social and human capital. Working paper no. 76, Institute for Strategy and Business Economics, University of Zurich, viewed 25 November 2013, from http://papers.ssrn.com/sol3/papers.cfm?abstract_id=1091089

Bandura, A., 1977, Social learning theory, Prentice-Hall, Englewood Cliffs, NJ.

BarNir, A., Watson, W.E. \& Hutchins, H.M., 2011, 'Mediation and moderated mediation in the relationship among role models, self-efficacy, entrepreneurial caree intention, and gender', Journal of Applied Social Psychology 41(2), 270-297. http://dx.doi.org/10.1111/j.1559-1816.2010.00713.x

Basu, A. \& Virick, M., 2008, 'Assessing entrepreneurial intentions amongst students: A comparative study', paper presented at the 12th Annual Meeting of the National Collegiate Inventors and Innovators Alliance, Dallas, 20-22th March, 79-8, viewed 21 November 2013, from http://www.nciia.net/conf08/assets/pub/ basu2.pdf

Bignotti, A., 2013, 'Factors relating to entrepreneurial career choice of secondary school students', Doctoral thesis, Department of Business Management University of Pretoria, viewed 23 May 2014, from http://hdl.handle.net/2263/ 33489

Bird, B., 1988, 'Implementing entrepreneurial ideas: The case for intention', Academy of Management Review 13(3), 442-453.

Boyd, N.G. \& Vozikis, G.S., 1994, 'The influence of self-efficacy on the development of entrepreneurial intentions and actions', Entrepreneurship Theory and Practice 18(4), 63-77.

Buelens, M. \& Izquierdo, E., 2008, 'Competing models of entrepreneurial intentions: The influence of entrepreneurial self-efficacy and attitudes', International Journal of Entrepreneurship and Small Business 13(1), 75-91.

Chen, T. \& Shen, C., 2012, 'Today's intern, tomorrow's practitioner? - The influence of internship programmes on students' career development in the hospitality industry', Journal of Hospitality, Leisure, Sport \& Tourism Education 11(1), 29-40. http://dx.doi.org/10.1016/j.jhlste.2012.02.008

Creswell, J.W., 2013, Qualitative inquiry and research design: Choosing among five approaches, 3rd edn., Sage Publications, Thousand Oaks, CA.

Cruz, N.M., Escudero, A.I.R., Barahona, J.H. \& Leitao, F.S., 2009, 'The effect of entrepreneurship education programmes on satisfaction with innovation behaviour and performance', Journal of European Industrial Training 33(3), 198-214. http://dx.doi.org/10.1108/03090590910950578

Daugherty, E.L., 2011, 'The public relations internship experience: A comparison of student and site supervisor perspective', Public Relations Review 37(5), 470-477. http://dx.doi.org/10.1016/j.pubrev.2011.09.010

Davidsson, P., 1995, 'Determinants of entrepreneurial intentions', paper presented at the RENT IX Workshop, Piacenza, 23-24th November, pp. 1-31, viewed 18 April 2013, from http://eprints.qut.edu.au/2076/

De Clercq, D., Honig, B. \& Martin, B., 2012, 'The roles of learning orientation and passion for work in the formation of entrepreneurial intention', International Small Business Journal 31(6), 652-676. http://dx.doi.org/10.1177/0266242 611432360
De Grez, L. \& Van Lindt, D., 2012, 'The influence of a "learning-by-doing" program on entrepreneurial perceptions of economics students', paper presented at the European Conference on Innovation and Entrepreneurship, Santarem, 21th September, pp. 156-162, viewed 27 November 2013, from http://0-search. proptember, pp. 156-162, viewed 27 November 2013, from http://0-search. proquest.com.innop
2 ?accountid $=14717$

De Pillis, E. \& DeWitt, T., 2008, 'Not worth it, not for me? Predictors of entrepreneurial intention in men and women', Journal of Asia Entrepreneurship and Sustainability 4(3), 1-13.

Dohse, D. \& Walter, S.G., 2010, The role of entrepreneurship education and regional context in forming entrepreneurial intentions. Working paper no. 2010/18, Institut d'Economia de Barcelona, viewed 25 November 2013, from http://www.econstor. eu/handle/10419/59753

Do Paço, A.M.F., Ferreira, J.M., Raposo, M., Rodrigues, R.G. \& Dinis, A., 2011, 'Behaviours and entrepreneurial intention: Empirical findings about secondary students', Journal of International Entrepreneurship 9(1), 20-38. http://dx.doi. students', Journal of International

Drennan, J., Kennedy, J. \& Redfrow, P., 2005, 'Impact of childhood experiences on the development of entrepreneurial intentions', International Journal of Entrepreneurship and Innovation 6(4), 231-238. http://dx.doi.org/10.5367/ 00000005775179801

Dutta, D.K., Li, J. \& Merenda, M., 2010, 'Fostering entrepreneurship: Impact of specialization and diversity in education', International Entrepreneurship and Management Journal 7(2), 163-179. http://dx.doi.org/10.1007/s11365-0100151-2

Falck, O., Heblich, S. \& Luedemann, E., 2012, 'Identity and entrepreneurship: Do school peers shape entrepreneurial intentions?', Small Business Economics 39(1), 39-59. http://dx.doi.org/10.1007/s11187-010-9292-5

Fayolle, A., 2013, 'Personal views on the future of entrepreneurship education', Entrepreneurship \& Regional Development 25(7-8), 692-701. http://dx.doi.org/1 $0.1080 / 08985626.2013 .821318$

Fayolle, A., Gailly, B. \& Lassas-Clerc, N., 2006, 'Assessing the impact of entrepreneurship education programmes: A new methodology', Journal of European Industria Training 30(9), 701-720. http://dx.doi.org/10.1108/03090590610715022

Fayolle, A. \& Liñán, F., 2014, 'The future of research on entrepreneurial intentions', Journal of Business Research 67(5), 663-666. http://dx.doi.org/10.1016/j. jbusres.2013.11.024

Gabrielsson, J. \& Politis, D., 2012, 'Work experience and the generation of new business ideas among entrepreneurs: An integrated learning framework', International Journal of Entrepreneurial Behaviour and Research 18(1), 48-74. http://dx.doi.org/10.1108/13552551211201376

Gault, J., Leach, E. \& Duey, M., 2010, 'Effects of business internships on job marketability: The employers' perspective', Education + Training 52(1), 76-88. http://dx.doi.org/10.1108/00400911011017690

Gird, A. \& Bagraim, J.J., 2008, 'The theory of planned behaviour as predictor of entrepreneurial intent amongst final-year university students', South African Journal of Psychology 38(4), 711-724. http://dx.doi.org/10.1177/0081246308 03800410

Herrington, M. \& Kew, J., 2014, GEM South Africa 2013 Report, Global Entrepreneurship Monitor, Cape Town, viewed 16 May 2014, from http://www.gemconsortium.org/ docs/3336/gem-south-africa-2013-report

Herrington, M., Kew, J. \& Kew, P., 2015, GEM South Africa 2014 Report, Global Entrepreneurship Monitor, Cape Town, viewed 11 May 2015, from http://www. gemconsortium.org/docs/3778/gem-south-africa-2014-report

Hmieleski, K.M. \& Corbett, A.C., 2008, 'The contrasting interaction effects of improvisational behavior with entrepreneurial self-efficacy on new venture performance and entrepreneur work satisfaction', Journal of Business Venturing 23(4), 482-496. http://dx.doi.org/10.1016/j.jbusvent.2007.04.002

James, B. \& Bell, J., 2013, 'Evaluating the effects of business pre-planning coursework on student entrepreneurial intentions', Small Business Institute National Conference Proceedings 37(1), 96-103.

Kautonen, T., Van Gelderen, M. \& Fink, M., 2013, 'Robustness of the theory of planned behavior in predicting entrepreneurial intentions and actions', Entrepreneurship Theory and Practice 39(3), 655-674. http://dx.doi.org/10.1111/etap.12056

Keat, O.Y., Selvarajah, C. \& Meyer, D., 2011, 'Inclination towards entrepreneurship among university students: An empirical study of Malaysian university students', International Journal of Business and Social Science 2(4), 206-220.

Kemelgor, B.H., D'Souza, R. \& Henley, G., 2011, 'The dynamics of entrepreneurial entry and firm performance of first career and second career entrepreneurs as mediated by prior knowledge', Southern Journal of Entrepreneurship 4(2), $18-45$.

Kibassa, F.M., 2012, 'Small business research: Upon finding definitions of entrepreneurship, entrepreneur and small firms', European Journal of Business and Management 4(15), 158-167.

Kickul, J., Wilson, F., Marlino, D. \& Barbosa, S.D., 2008, 'Are misalignments of perceptions and self-efficacy causing gender gaps in entrepreneurial intentions among our nation's teens?', Journal of Small Business and Enterprise Development 15(2), 321-335. http://dx.doi.org/10.1108/1462600081087 1709

Kim, H. \& Park, E.J., 2013, 'The role of social experience in undergraduates' caree perceptions through internships', Journal of Hospitality, Leisure, Sport \& Tourism Education 12(1), 70-78. http://dx.doi.org/10.1016/j.jhlste.2012.11.003

Krueger, N.F.J. \& Carsrud, A.L., 1993, 'Entrepreneurial intentions: Applying the theory of planned behaviour', Entrepreneurship and Regional Development 5(4), 315-330. http://dx.doi.org/10.1080/08985629300000020 
Kuijpers, M., Meijers, F. \& Gundy, C., 2011, 'The relationship between learning environment and career competencies of students in vocational education' Journal of Vocational Behavior 78(1), 21-30. http://dx.doi.org $/ 10.1016 / \mathrm{j}$. jub.2010.05.005

Kuratko, D.F., 2005, 'The emergence of entrepreneurship education: Development, trends, and challenges', Entrepreneurship Theory and Practice 29(5), 577-597. http://dx.doi.org/10.1111/j.1540-6520.2005.00099.x

Lazear, E.P., 2005, 'Entrepreneurship', Journal of Labor Economics 23(4), 649-680. http://dx.doi.org/10.1086/491605

Liñán, F., Rodríguez-Cohard, J.C. \& Rueda-Cantuche, J.M., 2011, 'Factors affecting entrepreneurial intention levels: A role for education', International Entrepreneurship and Management Journal 7(2), 195-218. http://dx.doi.org/10 1007/s11365-010-0154-z

Lucas, W.A., Cooper, S.Y., Ward, T. \& Cave, F., 2009, 'Industry placement, authentic experience and the development of venturing and technology self-efficacy', Technovation 29(11), 738-752. http://dx.doi.org/10.1016/j.technovation.2009. 06.002

Maina, R.W., 2011, 'Determinants of entrepreneurial intentions among Kenyan college graduates', KCA Journal of Business Management 3(2), 1-18, viewed 22 Novembe 2013, from http://www.ajol.info/index.php/kjbm/article/view/65968

Martínez, A.C., Levie, J., Kelley, D.J., Saemundsson, R.J. \& Schøtt, T., 2010, Global entrepreneurship monitor special report: A global perspective on entrepreneurship education and training, Global Entrepreneurship Monitor, London, viewed 17 education and training, Global Entrepreneurship Monitor, London, viewed 17 May 2014, from http://ww
on-education-and-training

Mason, C. \& Arshed, N., 2013, 'Teaching entrepreneurship to university students through experiential learning: A case study', Industry and Higher Education 27(6) 449-463. http://dx.doi.org/10.5367/ihe.2013.0180

Mertens, D.M., 2005, Research methods in education and psychology: Integrating diversity with quantitative and qualitative approaches, 2nd edn., Sage Publications, Thousand Oaks, CA.

Mlatsheni, C. \& Leibbrandt, M., 2011, 'Youth unemployment in South Africa: Challenges, concepts and opportunities', Journal of International Relations and Development 14(1), 118-126.

Moghaddam, J.M., 2011, 'Perceived effectiveness of business internships: Studen expectations, experiences, and personality traits', International Journal of Management 28(4), 287-303.

Nabi, G., Walmsley, A. \& Holden, R., 2013, 'Pushed or pulled? Exploring the factors underpinning graduate start-ups and non-start-ups', Journal of Education and Work 28(5), 481-506. http://dx.doi.org/10.1080/13639080.2013.805189

Narayanan, V.K., Olk, P.M. \& Fukami, C.V., 2010, 'Determinants of internship effectiveness: An exploratory model', Academy of Management Learning \& Education 9(1), 61-80. http://dx.doi.org/10.5465/AMLE.2010.48661191

Peltier, W. \& Scovotti, C., 2010, 'Enhancing entrepreneurial marketing education: The student perspective', Journal of Small Business and Enterprise Development 17(4), 514-536. http://dx.doi.org/10.1108/14626001011088705

Pittaway, L., Rodriguez-Falcon, E., Aiyegbayo, O. \& King, A., 2011, 'The role of entrepreneurship clubs and societies in entrepreneurial learning', International SmallBusinessJourna/29(1),37-57.http://dx.doi.org/10.1177/0266242610369876

Prabhu, V.P., McGuire, S.J., Drost, E.A. \& Kwong, K.K., 2012, 'Proactive personality and entrepreneurial intent: Is entrepreneurial self-efficacy a mediator or moderator?', International Journal of Entrepreneurial Behaviour \& Research 18(5), 559-586. http://dx.doi.org/10.1108/13552551211253937

Quan, X., 2012, 'Prior experience, social network, and levels of entrepreneurial intentions', Management Research Review 35(10), 945-957. http://dx.doi.org/10. $1108 / 01409171211272679$

Radu Lefebvre, M. \& Redien-Collot, R., 2013, “"How to do things with words": The discursive dimension of experiential learning in entrepreneurial mentoring dyads', Journal of Small Business Management 51(3), 370-393. http://dx.doi.org/10. $1111 /$ jsbm.12022
Sánchez, J.G., 2013, 'The impact of an entrepreneurship education program on entrepreneurial competencies and intention', Journal of Small Business Management 51(3), 447-465. http://dx.doi.org/10.1111/jsbm.12025

Saunders, M. \& Tosey, P., 2012. 'The Layers of research design', Rapport Winter (2012/2013), 58-59.

Sequeira, J., Mueller, S. \& McGee, J., 2007, 'The influence of social ties and selfefficacy in forming entrepreneurial intentions and motivating nascent behavior' Journal of Developmental Entrepreneurship 12(3), 275-293. http://dx.doi. org/10.1142/S108494670700068X

Shapero, A. \& Sokol, L., 1982, 'The social dimensions of entrepreneurship', in: C.A Kent, D.L. Sexton \& K.H. Vesper (eds.), Encyclopedia of entrepreneurship, PrenticeHall, Englewood Cliff, NJ.

Thurik, A.R., Carree, M.A., Van Stel, A. \& Audretsch, D.B., 2008, 'Does self-employment reduce unemployment?', Journal of Business Venturing 23(6), 673-686. http:// dx.doi.org/10.1016/j.jbusvent.2008.01.007

Van Auken, H., Fry, F.L. \& Stephens, P., 2006, 'The influence of role models on entrepreneurial intentions', Journal of Developmental Entrepreneurship 11(2), 157-167. http://dx.doi.org/10.1142/S1084946706000349

Vanevenhoven, J. \& Liguori, E., 2013, 'The impact of entrepreneurship education: Introducing the entrepreneurship education project', Journal of Small Business Management 51(3), 315-328. http://dx.doi.org/10.1111/jsbm.12026

Varghese, M.E., Parker, L.C., Adedokun, O., Shively, M., Burgess, W., Childress, A., et al., 2012, 'Experiential internships: Understanding the process of student learning in small business internships', Industry and Higher Education 26(5), 357-367. http://dx.doi.org/10.5367/ihe.2012.0114

Viviers, S., Solomon, G. \& Venter, C., 2013, 'Entrepreneurial intentions and behaviours of South African University students', The Southern African Journal of Entrepreneurship and Small Business Management 6, 1-20. http://dx.doi. org/10.4102/sajesbm.v6i1.30

Volery, T., Müller, S., Oser, F., Naepflin, C. \& Del Rey, N., 2013, 'The impact of entrepreneurship education on human capital at upper-secondary level', Journal of Small Business Management 51(3), 429-446. http://dx.doi.org/10.1111/jsbm. 12020

Walter, S.G. \& Dohse, D., 2009, The interplay between entrepreneurship education and regional knowledge potential in forming entrepreneurial intentions. Working paper no. 1549, Kiel Institute for the World Economy, Kiel, Germany, viewed 22 July 2014, from http://www.econstor.eu/handle/10419/28376

Wan, C.S., Yang, J.T., Cheng, S.Y. \& Su, C., 2013, 'A longitudinal study on internship effectiveness in vocational higher education', Educational Review 65(1), 36-55. http://dx.doi.org/10.1080/00131911.2011.634969

Wang, Y. \& Verzat, C., 2011, 'Generalist or specific studies for engineering entrepreneurs? Comparison of French engineering students' trajectories in two different curricula', Journal of Small Business and Enterprise Development 18(2), 366-383. http://dx.doi.org/10.1108/14626001111127124

Weible, R., 2009, 'Are universities reaping the available benefits internship programs offer?', Journal of Education for Business 85(2), 59-63. http://dx.doi.org/10. 1080/08832320903252397

Wilson, F., Kickul, J. \& Marlino, D., 2007, 'Gender, entrepreneurial self-efficacy, and entrepreneurial career intentions: Implications for entrepreneurship education', entrepreneurial career intentions: Implications for entrepreneurship education', Entrepreneurship Theory and
j.1540-6520.2007.00179.x

Zellweger, T., Sieger, P. \& Halter, F., 2011, 'Should I stay or should I go? Career choice intentions of students with family business background', Journal of Business Venturing 26(5), 521-536. http://dx.doi.org/10.1016/j.jbusvent.2010.04.001

Zhao, H., 2013, 'Turning small business interns into applicants: The mediating role of perceived justice', Journal of Business Venturing 28(3), 443-457. http://dx.doi. org/10.1016/j.jbusvent.2011.08.003

Zhao, H., Seibert, S.E. \& Hills, G.E., 2005, 'The mediating role of self-efficacy in the development of entrepreneurial intentions', Journal of Applied Psychology 90(6) 1265-1272. http://dx.doi.org/10.1037/0021-9010.90.6.1265 


\section{Appendix 1}

TABLE 1-A1: Survey results of South African tertiary institutions' entrepreneurship and business management programmes

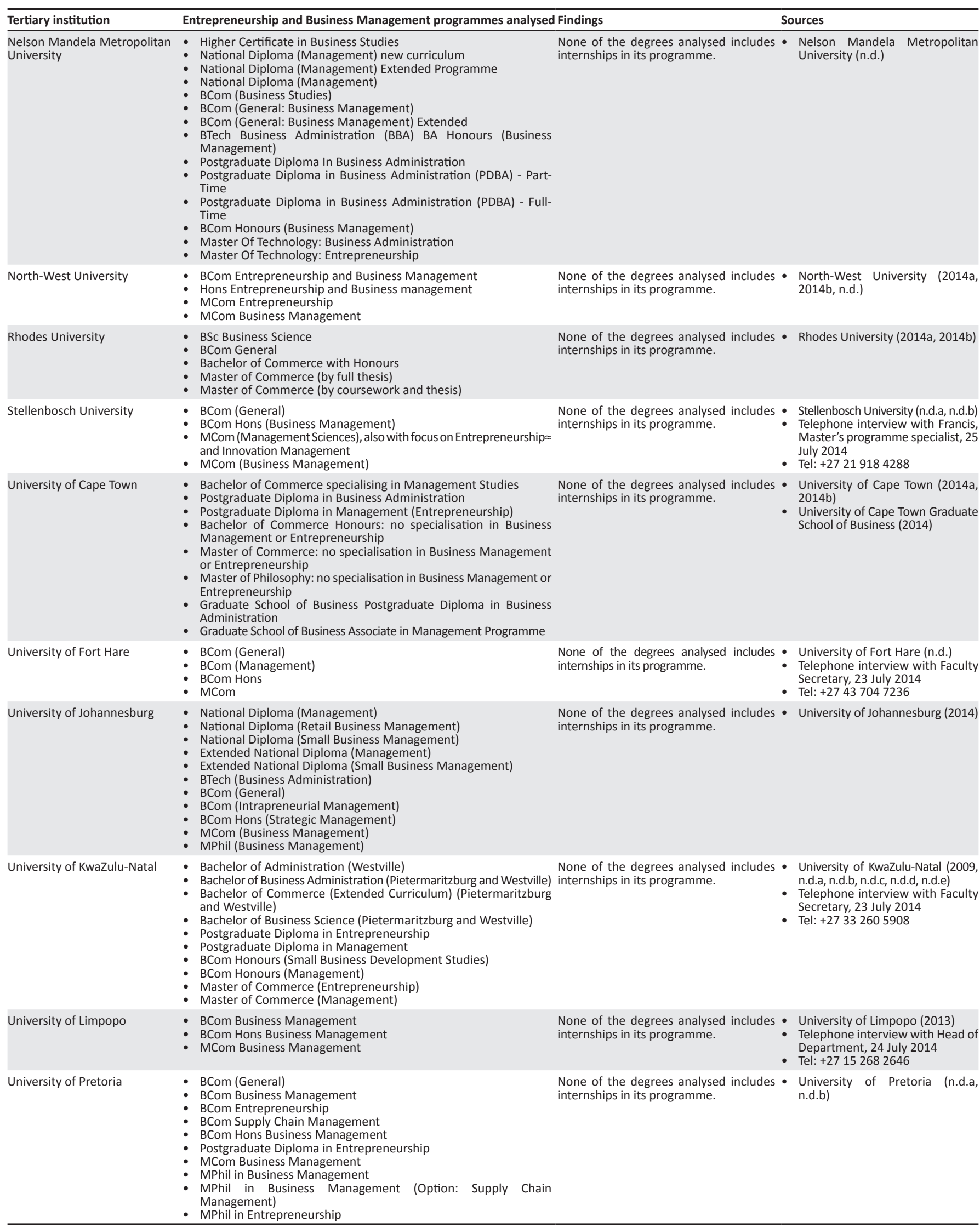




\begin{tabular}{|c|c|c|c|}
\hline Tertiary institution & Entrepreneurship and Business Management programmes analysed & Findings & Sources \\
\hline University of South Africa & $\begin{array}{l}\text { - Higher Certificate in Economic and Management Sciences } \\
\text { - National Diploma: Entrepreneurship } \\
\text { - Bational Diploma: Management } \\
\text { - Baccalaureus Technologiae: Business Administration } \\
\text { - Bachelor of Business Administration } \\
\text { - Bachelor of Commerce (Generic) } \\
\text { - Bachelor of Commerce (Entrepreneurship) } \\
\text { - Bachelor of Commerce (Management) } \\
\text { - Honours Bachere in Business Management } \\
\text { - Manours Bachelor of Administration in Business Management } \\
\text { - Master of Commerce in Business Management } \\
\text { Master of Business Administration (Coursework) }\end{array}$ & $\begin{array}{l}\text { None of the degrees analysed includes } \\
\text { internships in its programme. }\end{array}$ & $\begin{array}{l}\text { - University of South Africa (n.d.a, } \\
\text { n.d.b) }\end{array}$ \\
\hline University of the Free State & $\begin{array}{l}\text { - } \text { BCom (General) } \\
\text { - BCom (Entrepreneurship) } \\
\text { - BCom (General) extended programme } \\
\text { - BCom (General Management) } \\
\text { - } \text { BCom Hons Business Managent) extended programment } \\
\text { MCom Business Management }\end{array}$ & $\begin{array}{l}\text { None of the degrees analysed includes } \\
\text { internships in its programme. }\end{array}$ & $\begin{array}{l}\text { - University of the Free State } \\
\text { (2014a, 2014b, 2014c) } \\
\text { - University of the Free State } \\
\text { Business School (2014) }\end{array}$ \\
\hline University of the Western Cape & $\begin{array}{l}\text { - BCom (General) } \\
\text { - Advanced Diploma in Management } \\
\text { - } \text { BCom (Hons) in Business Administration } \\
\text { - MCom in Management }\end{array}$ & $\begin{array}{l}\text { None of the degrees analysed includes } \\
\text { internships in its programme. }\end{array}$ & $\begin{array}{l}\text { - University of the Western Cape } \\
\text { (2013a, 2013b) } \\
\text { - Telephone interview with Faculty } \\
\text { Secretary, } 23 \text { July } 2014 \\
\text { - Tel: }+27219593900\end{array}$ \\
\hline $\begin{array}{l}\text { University of the Witwaters- } \\
\text { rand }\end{array}$ & $\begin{array}{l}\text { - Bachelor of Commerce } \\
\text { - Postgraduate Diploma in Management } \\
\text { BCom Hons in Management } \\
\text { - MCom in Management } \\
\text { Creation }\end{array}$ & $\begin{array}{l}\text { None of the degrees analysed includes } \\
\text { internships in its programme. }\end{array}$ & $\begin{array}{l}\text { - University of the Witwatersrand } \\
\text { (n.d.a, n.d.b) } \\
\text { - Wits Business School (2014) } \\
\text { - Telephone conversation with } \\
\text { Faculty Officer, } 23 \text { July } 2014 \\
\text { - Tel: }+27117178003\end{array}$ \\
\hline University of Venda & $\begin{array}{l}\text { - Bachelor of Commerce in Business Management } \\
\text { - Bachelor of Commerce Honours in Business Management } \\
\text { - Master of Commerce (MCOM) in Business Management }\end{array}$ & $\begin{array}{l}\text { None of the degrees analysed includes } \\
\text { internships in its programme. }\end{array}$ & $\begin{array}{l}\text { - University of Venda (n.d.) } \\
\text { - Telephone conversation with } \\
\text { School Administrator, 24 July } \\
2014 \\
\text { - Tel: }+27159628869\end{array}$ \\
\hline University of Zululand & $\begin{array}{l}\text { - BCom (General) } \\
\text { - Bachelor of Commerce (Honours) } \\
\text { - Master of Commerce }\end{array}$ & $\begin{array}{l}\text { None of the degrees analysed includes } \\
\text { internships in its programme. }\end{array}$ & $\begin{array}{l}\text { - University of Zululand (n.d.a, } \\
\text { n.d.b) }\end{array}$ \\
\hline Walter Sisulu University & $\begin{array}{l}\text { - BTech Management } \\
\text { - BTech Business Administration } \\
\text { - Hochelor of Commerce (General) } \\
\text { - Master of Commerce }\end{array}$ & $\begin{array}{l}\text { None of the degrees analysed includes } \\
\text { internships in its programme. }\end{array}$ & - Walter Sisulu University (n.d.) \\
\hline $\begin{array}{l}\text { Cape Peninsula University of } \\
\text { Technology }\end{array}$ & $\begin{array}{l}\text { - ND: Entrepreneurship } \\
\text { - ND: Entrepreneurship (Extended) } \\
\text { - ND: Management } \\
\text { - ND: Management (Extended) } \\
\text { - } \text { BTech: Business Administration } \\
\text { - BTech: Management in Entrepreneurship } \\
\text { - BTech: Management } \\
\text { - BTech: Project Management } \\
\text { - } \text { BTech: Retail Business Management } \\
\text { - MTech: Business Administration (Research-Based) } \\
\text { - MTech: Business Administration (Course-Based) } \\
\text { - (Course-Based) } \\
\text { - MTech: Business Administration in Entrepreneurship (Research- } \\
\text { - MTech: Business Administration (Entrepreneurship) } \\
\text { - MTech: Retail Business Management }\end{array}$ & $\begin{array}{l}\text { None of the degrees analysed includes } \\
\text { internships in its programme. }\end{array}$ & $\begin{array}{l}\text { - Cape Peninsula University of } \\
\text { Technology (n.d.) }\end{array}$ \\
\hline Central University of Technology & - No degrees in Business Management or Entrepreneurship & N.A. & $\begin{array}{l}\text { - Central University of Technology } \\
(2014, \text { n.d.) }\end{array}$ \\
\hline Durban University of Technology & $\begin{array}{l}\text { - National Diploma: Management } \\
\text { - Bachelor of Technology: Management } \\
\text { - Bachelor of Technology: Business Administration } \\
\text { - Master of Technology: Business Administration }\end{array}$ & $\begin{array}{l}\text { The National Diploma in Management } \\
\text { includes internships in its curriculum. } \\
\text { Students have to find an internship } \\
\text { and work in the industry for } 3 \text { months } \\
\text { before the diploma can be awarded. }\end{array}$ & $\begin{array}{l}\text { - Durban University of Technology } \\
\text { (2014, n.d.a, n.d.b, n.d.c) } \\
\text { - Telephone conversation with } \\
\text { Faculty Secretary, Nonhlanhla } \\
\text { Mdakane, } 25 \text { July } 2014 \\
\text { - Tel: }+27313735147\end{array}$ \\
\hline $\begin{array}{l}\text { Mangosuthu University of } \\
\text { Technology }\end{array}$ & - No degrees in Business Management or Entrepreneurship & N.A. & $\begin{array}{l}\text { - Mangosuthu University of } \\
\text { Technology (n.d.) }\end{array}$ \\
\hline Tshwane University of Technology & $\begin{array}{l}\text { - National Diploma: Entrepreneurship } \\
\text { - National Diploma: Entrepreneurship (Extended curriculum } \\
\text { programme with foundation provision) } \\
\text { - National Diploma: Management } \\
\text { - National Diploma: Management (Extended curriculum } \\
\text { programme with foundation provision) } \\
\text { - Baccalaureus Technologiae: Business Administration } \\
\text { - Baccalaureus Technologiae: Management } \\
\text { - Magister Technologiae: Entrepreneurship }\end{array}$ & $\begin{array}{l}\text { None of the degrees analysed includes } \\
\text { internships in its programme. } \\
\text { The National Diploma in Entrepreneurship } \\
\text { has an experiential learning module in } \\
\text { 3rd year, but it is project-based training. }\end{array}$ & $\begin{array}{l}\text { - Tshwane University of Technology } \\
\text { (n.d.a, n.d.b, n.d.c, n.d.d, n.d.e., } \\
\text { n.d.f, n.d.g) } \\
\text { - Telephone conversation with } \\
\text { Department of Management } \\
\text { Administrator, } 25 \text { July } 2014 \\
\text { - Tel: }+27123825732\end{array}$ \\
\hline Vaal University of Technology & - No degrees in Business Management or Entrepreneurship & N.A. & $\begin{array}{l}\text { - Vaal University of Technology } \\
\text { (2014) }\end{array}$ \\
\hline
\end{tabular}




\section{Appendix 2}

\section{Sources of survey of university programmes}

Cape Peninsula University of Technology. n.d. Diplomas and degrees. [Online] Available from: http://www.cput.ac.za/academic/faculties/business/prospectus [Accessed: 2014-07-23].

Central University of Technology. 2014, Department of Business Management [Online] Available from: http://www.cut.ac.za/departments/department-ofbusiness-management/ [Accessed: 2014-07-23].

Central University of Technology. n.d. Prospectus 2014. [Online] Available from: http://www.cut.ac.za/wp-content/uploads/2013/04/Prospectus-2014-FINAL.pdf [Accessed: 2014-07-23].

Durban University of Technology. 2014. Career information, National Diploma: Management. [Online] Available from: http://ddt72ar9zv4px.cloudfront.net/wpcontent/uploads/career_leaflets/MANSCI\%20Management.pdf [Accessed: 2014content/u.

Durban University of Technology. n.d.a. Bachelor of Technology: Management. [Online] Available from: http://www.dut.ac.za/sites/default/files/bsu/Bachelor Technology_Management_(BTech).pdf [Accessed: 2014-07-23]

Durban University of Technology. n.d.b. Handbook for 2014, Faculty of Management Sciences, Department of Entrepreneurial Studies and Management. [Online] Available from: http://www.dut.ac.za/sites/default/files/handbooks/MANSCl\%20 Available from: http://www.dut.ac.za/sites/default/files/handbooks/M
Entrepren\%20Studies\%20and\%20Mgt.pdf [Accessed: 2014-07-23].

Durban University of Technology. n.d.c. Short courses. [Online] Available from: http:// www.dut.ac.za/sites/default/files/bsu/short_courses.pdf [Accessed: 2014-07-23].

Mangosuthu University of Technology. n.d. Faculty of Management Sciences. [Online] Available from: http://www.mut.ac.za/faculties/managementsciences. [Accessed: 2014-07-23].

Nelson Mandela Metropolitan University. n.d. Degrees, diplomas \& certificate. [Online] Available from: http://www.nmmu.ac.za/Courses-on-offer/Degrees,diplomas-certificates [Accessed: 2014-07-21].

North-West University. 2014a. Faculty of Economic and Management Sciences, qualifications undergraduate. [Online] Available from: http://www.nwu.ac.za/pfems/undergrade.html [Accessed: 2014-07-21].

North-West University. 2014b. Postgraduate studies. [Online] Available from: http:// www.nwu.ac.za/postgraduate-programmes-potchefstroom\#businessman www.nwu.ac.za/postg
[Accessed: 2014-07-21].

North-West University. n.d. Economic and Management Sciences. [Online] Available from: http://www.nwu.ac.za/sites/www.nwu.ac.za/files/files/p-prospective students/Eng_Faculty_Booklets/economic.pdf [Accessed: 2014-07-21].

Rhodes University. 2014a. Commerce degree structure. [Online] Available from: http://www.ru.ac.za/admissiongateway/application/curriculumselection/ commerce/\#d.en.71115 [Accessed: 2014-07-22].

Rhodes University. 2014b. Postgraduate gateway. [Online] Available from: http:// www.ru.ac.za/postgraduategateway/gateway/ [Accessed: 2014-07-22].

Stellenbosch University. n.d.a. 2015 all in one undergraduate prospectus. [Online] Available from: http://www.maties.com/assets/prospectus/eng_prospectus.pdf [Accessed: 2014-07-22].

Stellenbosch University. n.d.b. Faculty of Economic and Management Sciences, calendar 2013, part 10. [Online] Available from: http://stbweb01.stb.sun.ac.za/ university/jaarboek/2013/2013_WEB_EMS.pdf [Accessed: 2014-07-22].

Tshwane University of Technology. n.d.a. Baccalaureus Technologiae: Business Administration. [Online] Available from: http://www.tut.ac.za/Prospectus/2014/ pdf/6/Management \% 20 and \% 20Entrepreneurship/BTech BusinessAdministration.pdf [Accessed: 2014-07-23].

Tshwane University of Technology. n.d.b. Baccalaureus Technologiae Management. [Online] Available from: http://www.tut.ac.za/Prospectus/2014/ pdf/6/Management $\% 20$ and $\% 20$ Entrepreneurship/BTech Management.pdf pdf/6/Management\%20
[Accessed: 2014-07-23].

Tshwane University of Technology. n.d.c. Magister Technologiae: Entrepreneurship. (Structured). [Online] Available from: http://www.tut.ac.za/Prospectus/2014/ pdf/6/Management $\% 20$ and $\% 20$ Entrepreneurship/MTech $\mathrm{pdf} / 6 / \mathrm{M}$ a nag e m e n $\mathrm{t} \% 20$ a nd $\% 20 \mathrm{Ent}$ re pre
Entrepreneurship(Structured).pdf [Accessed: 2014-07-23].

Tshwane University of Technology. n.d.d. National Diploma: Entrepreneurship. [Online] Available from: http://www.tut.ac.za/Prospectus/2014/pdf/6/Management $\% 20$ and\%20Entrepreneurship/NDip_Entrepreneurship.pdf [Accessed: 2014-07-23].

Tshwane University of Technology. n.d.e. National Diploma: Entrepreneurship. (Extended curriculum programme with foundation provision). [Online] Available from: http:// www.tut.ac.za/Prospectus $/ 2014 / \mathrm{pdf} / 6 /$ Management $\% 20$ and $\% 20$ Entrepreneurship/NDip_Entrepreneurship(Extended).pdf [Accessed: 2014-07-23].

Tshwane University of Technology. n.d.f. National Diploma: Management. [Online] Available from: http://www.tut.ac.za/Prospectus/2014/pdf/6/Management $\% 20$ and\%20Entrepreneurship/NDip_Mangement.pdf [Accessed: 2014-07-23].

Tshwane University of Technology. n.d.g. National Diploma: Management. (Extended curriculum programme with foundation provision). [Online] Available from: http:// www.tut.ac.za/Prospectus/2014/pdf/6/Management $\% 20$ and $\% 20$ Entrepreneurship/NDip_Management(Extended).pdf [Accessed: 2014-07-23].
University of Cape Town. 2014a. Faculty of Commerce, postgraduate studies. [Online] Available from: http://www.uct.ac.za/downloads/uct.ac.za/apply/handbooks/ Handbook6BCommercePostgraduateStudies2014.pdf [Accessed: 2014-07-23].

University of Cape Town. 2014b. Faculty of Commerce, undergraduate studies. [Online] Available from: http://www.uct.ac.za/downloads/uct.ac.za/apply/handbooks/ Available from: http://www.uct.ac.za/downloads/uct.ac.za/apply/handbooks/
Handbook6ACommerceUndergraduateStudies2014.pdf [Accessed: 2014-07-22].

University of Cape Town Graduate School of Business. 2014. Learning programmes. [Online] Available from: http://www.gsb.uct.ac.za/s.asp?p=28 [Accessed: 201407-22].

University of Fort Hare. n.d. Faculty of Management and Commerce. [Online] Available from: http://www.ufh.ac.za/files/FACULTY\%200F\%20MANAGEMENT $\% 20$ AND $\% 20$ COMMERCE $\% 20-\%$ 20ACCOUNTING\%2OPROSPECTUS\%20ENTRY.pdf [Accessed: 2014-07-23].

University of Johannesburg. 2014. Faculty of Management, rules and regulations, undergraduate and postgraduate. [Online] Available from: http://www.uj.ac.za/ EN/Faculties/Documents/FOM\%20FACULTY\%20RULES\%20AND\%20 REGULATIONS\%202014\%20MANAGEMENT\%20FINAL\%2028.11.13.pdf [Accessed: 2014-07-22].

University of KwaZulu-Natal. 2009. Postgraduate Diploma in Entrepreneurship. [Online] Available from: http://gsbl.ukzn.ac.za/Programmes/Postgraduate[Online] Available from: http://gsbl.ukzn.ac.za/Programm
diplomas/PGDipEntrepreneurship.aspx [Accessed: 2014-07-23].

University of KwaZulu-Natal. n.d.a. Entrepreneurship. [Online] Available from: http:// management.ukzn.ac.za/Libraries/Postgraduate_Programmes/Entrepreneurship. sflb.ashx [Accessed: 2014-07-23].

University of KwaZulu-Natal. n.d.b. Management. [Online] Available from: http:// management.ukzn.ac.za/Libraries/Postgraduate_Programmes/management.sflb. management.ukzn.ac.za/Librarie
ashx [Accessed: 2014-07-23].

University of KwaZulu-Natal. n.d.c. Postgraduate application guide 2014. [Online] Available from: http://applications.ukzn.ac.za/Libraries/prospectus/2014_Postgraduate Application_Guide.sflb.ashx [Accessed: 2014-07-23].

University of KwaZulu-Natal. n.d.d. Postgraduate diploma programmes. [Online] Available from: http://management.ukzn.ac.za/Libraries/Postgraduate_Programmes/ postgraduate-diploma.sflb.ashx [Accessed: 2014-07-23].

University of KwaZulu-Natal. n.d.e. Undergraduate prospectus 2015. [Online] Available from: http://applications.ukzn.ac.za/Files/2015\%20Undergraduate $\% 20$ Prospectus.pdf [Accessed: 2014-07-23].

University of Limpopo. 2013. Economics and management offers. [Online] Available from: http://www.ul.ac.za/index.php?Entity=Economics $\% 20$ and $\% 20$ Management [Accessed: 2014-07-23].

University of Pretoria. n.d.a. Economic and Management Sciences 2014. [Online] Available from: http://web.up.ac.za/sitefiles/file/publications/2014/yearbooks/ EMS_undergraduate_Yearbook-2014(eng).PDF [Accessed: 2014-07-23].

University of Pretoria. n.d.b. Economic and Management Sciences 2014, postgraduate [Online] Available from: http://web.up.ac.za/sitefiles/file/publications/2014/ yearbooks/Economic_and_Management_Sciences-(Postgraduate)-2014.PDF [Accessed: 2014-07-23].

University of South Africa. n.d.a. Master's and doctoral studies. [Online] Available from: http://www.unisa.ac.za/qualificationsMD/ [Accessed: 2014-07-22].

University of South Africa. n.d.b. Undergraduate and honours studies, College of Economic and Management Science. [Online] Available from: http://www.unisa. ac.za/qualifications/index.asp?link=http://www.unisa.ac.za/qualifications/ Navigation/Alph_3_99.html [Accessed: 2014-07-22].

University of the Free State. 2014a. Faculty of Economic and Management Sciences, Bloemfontein campus, undergraduate, Rule book 201. [Online] Available from: http://apps.ufs.ac.za/dl/yearbooks/221_yearbook_eng.pdf [Accessed: 2014-07-23].

University of the Free State. 2014b. Faculty of Economic and Management Sciences, postgraduate, rule book 2014. [Online] Available from: http://apps.ufs.ac.za/dl/ yearbooks/223_yearbook_eng.pdf [Accessed: 2014-07-23].

University of the Free State. 2014c. Faculty of Economic and Management Sciences, Qwaqwa campus, undergraduate, rule book 2014. [Online] Available from: http:// apps.ufs.ac.za/dl/yearbooks/222_yearbook_eng.pdf [Accessed: 2014-07-23].

University of the Free State Business School. 2014. Faculty of Economic and Management Sciences, Business School rules 2014. [Online] Available from: http://apps.ufs.ac.za/ $\mathrm{dl} /$ yearbooks/225_yearbook_eng.pdf [Accessed: 2014-07-23].

University of the Western Cape. 2013a. Prospectus, current postgraduate and research focuses. [Online] Available from: http://prospectus.uwc.ac.za/educate/ research-post-grad/current-postgraduate-studies-and-research-focuses/ [Accessed: 2014-07-23].

University of the Western Cape. 2013b. Prospectus, Faculty of Economic and Management Sciences. [Online] Available from: http://prospectus.uwc.ac.za/ educate/faculty-of-economic-and-management-sciences/ [Accessed: 2014-07-23].

University of the Witwatersrand. n.d.a. Guide for applicants 2014, commerce, law and management. [Online] Available from: http://www.wits.ac.za/files/9l8dh 164396001359705025.pdf [Accessed: 2014-07-23].

University of the Witwatersrand. n.d.b. Postgraduate programmes 2014/2015, Faculty of Commerce, Law and Management. [Online] Available from: http:// www.wits.ac.za/files/o90ag_472767001399021082.pdf [Accessed: 2014-07-23].

University of Venda. n.d. Student brochure. [Online] Available from: http://www. univen.ac.za/docs/UnivenStudentBrochure2014low.pdf [Accessed: 2014-07-23].

University of Zululand. n.d.a. Faculty of Commerce, Administration and Law, postgraduate programmes. [Online] Available from: http://www.unizulu.ac.za/ images/POSTGRADUATE\%2OPROGRAMMES.pdf [Accessed: 2014-07-23]. 
University of Zululand. n.d.b. Faculty of Commerce, Administration and Law, undergraduate programmes. [Online] Available from: http://www.unizulu.ac.za/ images/UNDERGRADUATE\%2OPROGRAMMES.pdf [Accessed: 2014-07-23].

Vaal University of Technology. 2014. Faculty of Management Sciences. [Online] Available from: http://www vut ac za/images/stories/admissions/management $\% 20$ science $\% 20$ booklet $\% 202014$.pdf [Accessed: 2014-07-23].
Walter Sisulu University. n.d. Prospectus 2014, Faculty of Business, Management Sciences and Law. [Online] Available from: http://www.wsu.ac.za/wsuV1/img/ FBMSL\%20prospectus $\% 202014 \% 20$ low-res.pdf [Accessed: 2014-07-23].

Wits Business School. 2014. MM in Entrepreneurship and New Venture Creation [Online] Available from: http://www.wbs.ac.za/programmes/degrees $/ \mathrm{mm}$ in entrepreneurship_and_new_venture_creation [Accessed: 2014-07-23]. 